\title{
Idea współczesnego uniwersytetu jako idea działania bezwarunkowego
}

\author{
Politycy chca, by nauka skupiata się na pilnych potrzebach. \\ Ale większosśc wynalazków, które wptynęty na jakosśc życia, \\ pochodzi zabstrakcyjnych badań motywowanych ciekawościa.
}

Leon Ledermann

Nauczanie polega zawsze na akcie stowa performatywnego, nawet jeśli wiedza, obiekt, zawartość tego, co się wyznaje, czego się naucza lub praktykuje, pozostaje, wtaściwie na porzadku teoretycznym lub twierdzacym. Jacques Derrida, Université sans condition

Wiele jest pomysłów na rozwój uniwersytetu i jego ideę forpoczty niosącej przysłowiowy kaganek wiedzy. Narastająca liczba publikacji dotyczących owej instytucji pokazuje, że budowanie takiej idei ma odwieczny i uwarunkowany jakby „poza” historią sens (idea akademii stanowi niejako aksjomat kultury i społeczeństwa w ich ogólnym rozumieniu). Jak pokazują z kolei historyczne przykłady, idea uniwersytetu od czasów antycznych była przyczółkiem ochrony tego, co stanowi absolutną podstawę każdego społeczeństwa, budowanego poprzez edukację rozumianą jako dialog. Sens owej idei w historii można lapidarnie sprowadzić do 
tego, co Borges określił jako „najlepszą rzecz, jaką wymyślili antyczni Grecy”. To bowiem dialog ustanawiał u Platona i Arystotelesa, twórców akademii (w gaju Akademosa), historyczną cezurę początku instytucji „Uniwersytetu”. Funkcją podstawową akademii, która przeradza się w uniwersytet, jest idea universitas, upowszechniania tego, co odmienne, i umieszczania tego w przestrzeni societas i communitas zarazem.

W szkicu tym nie będę zajmować się jednak ani analizą sposobów funkcjonowania uniwersytetu, ani jego możliwościami „technicznymi” w obliczu ujednolicania systemów edukacyjnych, przejdę natomiast do pewnej konkretnej wizji uniwersytetu w czasach globalizacji i jego „metafizycznych”, historycznych i etycznych możliwości w obliczu upadku owej instytucji jako takiej.

W krótkiej i niezwykle lapidarnej książce Université sans condition, Jacques Derrida nie umieszcza początku „współczesnego” uniwersytetu w Grecji, lecz szuka jego źródeł u zarania nowoczesności, czyli w epoce średniowiecza i renesansu, w których kształtowały się podstawowe funkcje pierwszych wielkich miast i mecenasów, i w których podstawowe wartości „nowożytnego” uniwersytetu musiały dojść do głosu i wziąć górę nad uniwersytetem jako dziedziną kościoła i scholastycznego uwięzienia w perspektywie religii.

Derrida domaga się od uniwersytetu czegoś, co stanowi swoisty paradoks, ale co w obliczu problemów współczesnego świata potrzebuje uprawomocnienia. Jest to o tyle trudne, że francuski filozof żąda swego rodzaju stwarzania - by ująć sprawę bez uciekania w retorykę - „gramatyki wyjątków”. Nie to bowiem, co ogólne i ogólnie uznane miałoby stać się nośnikiem siły i wartości uniwersytetu jako tej instytucji, która „myśli”, ale właśnie to, co jednostkowe i pojedyncze. Domaga się tego, co stanowi implicite podstawę dekonstrukcji, która - wedle lapidarnego określenia - nie jest tym, o czym wtaśnie myślisz, a w obliczu postawionego twierdzenia, jest właśnie tym wszystkim, co na razie poza prawem, ale domaga się uznania; poza literą, ale domaga się opisu; co pojedyncze i domaga się dopuszczenia do przestrzeni głosu etc., etc.

Chodzi więc o to, że w przestrzeni dzisiejszej uczelni, zgodnej z jej nowoczesnym rozumieniem, nie to, co uznawalne za prawdę jest prawdziwe, ale to, co prawdę tworzy na zasadzie performatywu. W swej książce na temat idei „uniwersytetu przyszłości” Derrida mówi:

Odnoszę się tutaj więc do uniwersytetu, który byłby tym, czym zawsze powinien być lub dążł do przedstawiania, to znaczy, począwszy od swojej zasady i w zasadzie »rzeczy«, »sprawy« autonomicznej, bezwarunkowo wolnej w swojej instytucji, w swoim słowie, w swoim piśmie, w swojej myśli. W myśli, piśmie, słowie, 
które nie byłyby jedynie archiwami lub wytworami wiedzy lecz daleko od jakiejkolwiek utopijnej neutralności, dziełami performatywnymi ${ }^{1}$.

Właśnie bowiem zdania performatywne stanowią - mówiąc najprościej - podstawę myślenia w przestrzeni akademii. Aby coś mogło stać się, musi zostać wpierw wypowiedziane, z przestrzeni idei winno przenieść się w przestrzeń rzeczywistości. Derrida nie mówi więc, iż uniwersytet nie powinien godzić się na - by odnieść się do trwającej w ostatnim czasie dyskusji na temat edukacji i ująć rzecz w wielkim uproszczeniu - „hodowanie troglodytów”2. Na ten poziom w ogóle nie zstępuje i nie podaje żadnych gotowych rozwiązań. Tworzy niejako idę̨ normatywną uniwersytetu, który z samej idei powinien budować przestrzeń dekonstrukcji i krytyki, która nie pozwoliłaby na zatrzymanie się myślenia i praktyki w pewnym „miejscu”, które „zasklepi się” w nowy sens; w miejscu zadowolenia z siebie, z uznania, że coś jest prawdą ostateczną, której należy się bezwzględnie poddać. Jak powinna wyglądać idea „działalności” uniwersytetu? Owa działalność powinna być stałością jedynie jako płynność myśli i demokratyczne dopuszczenie owej myśli do głosu, nawet jeśli sprzeciw okazałby się głośniejszy niż owa pojedyncza myśl. Jak powinno wyglądać działanie profesora, jego, jak mówi Derrida, „profesja”? Winna być nade wszystko działaniem w myśleniu ku prawdzie i w pracy myślenia jako praktycznego określenia wyznania wiary profesora uniwersytetu.

$\mathrm{Na}$ takiej zasadzie Derrida odnosi się do trzech konstytutywnych rzeczy na uniwersytecie jutra: 1) zawodu profesora, 2) omówienia profesji profesora oraz szerokiego omówienia fenomenu samej „pracy”, oraz 3) wyznania wiary. „Nie odważyłbym się tutaj - powiada autor - zadać pytania, kto miałby być takim profesorem, bo być może powinniśmy wspólnie przeanalizować pewne dziedzictwo, a w każdym razie pewne pokrewieństwo pomiędzy przyszłością profesji akademickiej, to znaczy profesji profesora, a zasadą autorytetu, który się wprost z niej wysuwa, jak również z wyznaniem wiary”. W ciekawej analizie Derrida wiąże zawód profesora z czynnością nauczania, po czym w kilku słowach określa, na czym polega w ogóle profesja nauczycielska i z czym się ta „praca” wiąże:

1 J. Derrida, Université sans condition, Paris 2001. Wszystkie cytaty pochodzą z polskiego przekładu dzieła, które obecnie składane jest do druku.

2 Debata odbywała się w odniesieniu do „polskich uczelni”, zaś artykuł, do którego się tutaj jedynie ogólnikowo odnoszę, wyszedł spod pióra Andrzeja Kraśniewskiego, „Rzeczpospolita” 03. 07. 2012. 
Nauczać" to słowo pochodzenia łacińskiego (profiteor, professus sum; pro et fateor, co zaś z kolei oznacza, skąd także pochodzi baśń, a więc jakieś „tak jakby”), oznacza, we francuskim tak jak i w angielskim, deklarować otwarcie, deklarować publicznie. W angielskim, podaje Oxford English Dictionary, ma znaczenie czysto religijne do 1300. „To make one’s profession”, oznacza wówczas „to make the vows of some religious order". Deklaracja tego, który naucza jest, w pewien sposób, deklaracją performatywną. Angażuje poprzez akt zaprzysięgłej wiary, przysięgi, świadectwa, manifestacji, zaświadczenia lub obietnicy. Jest to, w mocnym znaczeniu tego słowa, właśnie zaangażowanie. Nauczać to dawać w zastaw, angażując swoją odpowiedzialność.

I na koniec przechodzi Derrida do określenia, czym jest dla niego owo wyznanie nauczyciela akademickiego:

Uczynić z czegoś wyznanie - powiada - to zadeklarować głośno, czym się jest, w co się wierzy, czym chce się być, wymagając od innego wiary na słowo w ową deklarację. Kładę szczególny nacisk na wartość performatywną deklaracji, która naucza obiecując. Należy mocno zaznaczyć, że wyrażenia twierdzące oraz dyskursy czystej wiedzy na uniwersytecie lub gdziekolwiek indziej, nie wywodzą się jako takie i sensu stricte z zawodu. Wywodzą się one, być może, z „rzemiosła” (kompetencja, wiedza, umiejętność), lecz z pewnością nie z zawodu rozumianego w rygorystycznym sensie. Dyskurs profesji jest zawsze, w taki bądź inny sposób, wolnym wyznaniem wiary; przekracza czystą wiedzę techno-naukową w zaangażowaniu odpowiedzialności.

Ostatnią kwestią, jaką tutaj przywołam (choć nie ostatnią, jaką omawia Derrida), będzie fenomen pracy „na” uniwersytecie, pracy rozumianej szczególnie, wartej więc przywołania.

Praca - powiada Derrida - to nie tylko działanie lub praktyka. Można działać, nie pracując. Nie jest pewne, że jakakolwiek praxis, w szczególności praktyka teoretyczna, stanowi pracę sensu stricte. I przede wszystkim, komukolwiek, kto pracuje, nie są przyznane nazwa i statut pracownika. Agent czy też podmiot, który pracuje, operator, nie zawsze jest nazywany pracownikiem [laborator]. Sens wydaje się w ten sposób zmieniać, przechodząc od czasownika do rzeczownika: praca tego, który pracuje, w ogólności, nie zawsze jest pracą [labeur] jakiegoś „pracownika”.

Jako że z pracą wiąże się ustanawianie społecznych, ekonomicznych i politycznych relacji, a więc relacji „stopni” i „funkcji” przed nimi podążających, Derrida wypowiada się na temat wywołującego każdorazowo dyskusje statusu profesora z jednej, pracownika administracyjnego z drugiej, oraz odbiorcy pracy i studenta z trzeciej strony. 
W ten sposób na uniwersytecie - powiada - pomiędzy tymi wszystkimi, którzy w taki lub inny sposób mają tam pracować (nauczyciele, personel zarządzający lub administracyjny, naukowcy, studenci), [...] studenci nie nazywają siebie zazwyczaj „pracownikami” aż do momentu, kiedy nie będą otrzymywać regularnie jakiejś płacy [merces], rozumianej jako swoisty towar na rynku, działalność jakiegoś zawodu lub profesji. Samo stypendium do tego nie wystarczy. Nieważne że student dużo pracuje, jest traktowany jako pracownik z zasady jego obecności na rynku i jeśli oddaje się [...] jakiejkolwiek pracy, na przykład [...] pracy teaching assistant. O ile studiuje, czysto i prosto, i nawet jeśli pracuje dużo, student nie jest uważany za pracownika. Nawet jeśli, położę na tym nacisk za chwilę, nie każdy zawód jest profesją, pracownik jest kimś, kogo praca jest rozpoznawalna jako zawód lub jako profesja na rynku. (Cała ta semantyka społeczna jest zakorzeniona, jak o tym wiecie, w długiej historii społeczno-ideologicznej, która biegnie co najmniej aż do czasów chrześcijańskiego średniowiecza). Można więc pracować dużo, mimo że pracownik nie jest rozpoznany jako taki w społeczeństwie.

Praca bowiem nie tyle opiera się nawet na zasadzie, że ktoś pracuje „długo”, ale działa jako praca w oparciu o to, że pozostaje po i poza czasem działania, oraz włącza się w społeczny obieg jako fakt rzeczywisty i zarazem fakt aktualny.

Reasumując: jaka jest, zdaniem Derridy, definicja uniwersytetu w klasycznym rozumieniu? To definicja uniwersytetu jako miejsca „identycznego sobie”, na którym produkuje się wiedzę i praktykuje się „studia”, któremu wyznaczone jest określone, niezmienne prawo i zespół zasad kierujących tak rozumianą instytucją, w końcu ustanawia się wiedze o możliwościach: normatywnych, preskryptywnych, performatywnych i fikcjonalnych, które stanowią przedmiot nauk humanistycznych.

Uniwersytet jutra powinien, zgodnie z postulatem Kanta (wyrażonym w Krytyce wtadzy sądzenia), na którego powołuje się kilkakrotnie autor Uniwersytetu bezwarunkowego, zapewniać „bezwarunkową” wolność mówienia prawdy, bo właśnie ową wolność zapewnia sama instytucja i praca akademicka. W tym miejscu jednostka, jak i instytucja spotykają się w przestrzeni wzajemnej - bo budowanej poprzez relację i umowę - wolności: ta „ostatnia zasada”: „mówić publicznie wszystko, co uważa się za prawdziwe i o czym uważa się, że należy powiedzieć ale jedynie wewnątrz uniwersytetu", jest ostateczną zasadą etycznego działania i postępowania, która oddziałuje dziś ponad granicami „narodowymi” i „państwowymi”. Przestrzeń uniwersytetu jest bowiem od zawsze na tyle niezależna, a przez swą niezależność wyjątkowa, że „może być symbolicznie chroniona przez pewien rodzaj immunitetu absolutnego, tak jakby jej wnętrze było nietykalne”. 


\section{Cytowanie:}

A.Z. Jaksender, Idea wspótczesnego uniwersytetu jako idea dziatania bezwarunkowego, „Praktyka Teoretyczna” nr 1(7)/2013, http://www.praktykateoretyczna.pl/PT_nr7_2013_NOU/04.Jaksender.pdf (dostęp dzień miesiąc rok) 